Article

\title{
The Relationships among Leisure Involvement, Organizational Commitment and Well-Being: Viewpoints from Sport Fans in Asia
}

\author{
Su-Lan Pan ${ }^{1}{ }^{\mathbb{D}}$, Homer C. Wu ${ }^{2}$, Alastair M. Morrison ${ }^{3, * \mathbb{D}}$, Min-Tzu Huang ${ }^{4}$ \\ and Wen-Shiung Huang ${ }^{5}$ (i) \\ 1 School of Tourism \& Hospitality Management and Institute for Development of Cross-strait Small and \\ Medium Enterprises, Hubei University of Economics, Wuhan 430205, China; sandypan2015@163.com \\ 2 Graduate Program of Sustainable Tourism and Recreation Management, \\ National Taichung University of Education, Taichung 40306, Taiwan; hcwu@mail.ntcu.edu.tw \\ 3 National Kaohsiung University of Hospitality and Tourism, Kaohsiung, Taiwan \\ 4 Hualien Sun Dance High School, Hualien 97367, Taiwan; wendy75328@gmail.com \\ 5 Department of Tourism and Leisure Management, Ling Tung University, Taichung 40852, Taiwan; \\ didon@mail.uma.org.tw \\ * Correspondence: alastair@belletourism.com
}

Received: 18 February 2018; Accepted: 28 February 2018; Published: 8 March 2018

\begin{abstract}
Baseball spectating is one of the most popular leisure activities in Asia. Leisure participants with high well-being levels usually demonstrate loyal behavior to the teams they follow. Previous research indicates that professional sport fans are serious leisure participants and their participation has career qualities. The goal of this research was to investigate the relationship of leisure involvement with the well-being of professional sport fans and the possible mediating effect of organizational commitment, a career-related characteristic, on well-being. Some 406 fans of the Brother Elephants Baseball Team in Taiwan were surveyed. The results showed that leisure involvement positively and significantly influenced fans' well-being and organizational commitment partially mediated the influence of leisure involvement on well-being. This study pioneers the integration of leisure involvement, well-being and organizational commitment in the context of a Professional Baseball League team within Asia. Implications and future research directions are presented.
\end{abstract}

Keywords: leisure involvement; organizational commitment; serious leisure; professional sport fans; well-being

\section{Introduction}

In Asia, professional sport is not yet as vibrant as in the USA and Europe and the current population of sport fans is smaller. Since 1970, Taiwan's Little League Baseball, Junior League Baseball and Senior League Baseball teams have repeatedly won international competitions. The Chinese Professional Baseball League (CPBL) began in Taiwan in 1989 and is the sixth professional baseball league in the world. The total attendance reached 10 million in 1997 [1] but the population of Taiwan is only 23 million. These statistics indicate that baseball spectating is a favorite leisure activity that has blended into the lifestyles of Taiwanese.

The success of professional sports is derived from fans' support and developing a loyal fan base is a fundamental aim of professional sport organizations [2]. Each CPBL team is managed by an enterprise. Usually, loyal fans travel to baseball fields around Taiwan to support their teams [3,4]. Hence fostering loyal fans is very important to every CPBL team. Fans benefit in many ways from the association with teams, just as do the loyal customers of other companies. Much previous academic 
research has focused on sport fans' loyalty. Some researchers assessed the attitudinal or behavioral loyalty of sport fans [5-10]. Others analyzed fans' sponsoring or consumption intentions [11-13]. However, if fans cannot obtain happiness or well-being from watching sports or participating in sport activities, the relationship between fans and their teams will not be sustainable. Well-being or happiness has positive affect and motivations that encourage people to pursue certain activities and communicate favorable word of mouth about them [14]. For example, Chiu, Cheng, Huang and Chen investigated users' experiences with social network sites, showing that subjective well-being positively influenced loyalty toward SNSs [15]. However, studies on well-being generated by sport remain scarce [16].

In Taiwan, baseball spectating is a favorite leisure activity and baseball fans represent a large community. The relationship between community well-being and community development intersect; good community development fosters community well-being [17]. Hence, considering the well-being of baseball fans contributes to a better understanding of community well-being and community development.

The concept of serious leisure emerged through the work of Stebbins, which he defined as "the systematic pursuit of an amateur, hobbyist, or volunteer activity that is sufficiently substantial and interesting for the participant to find a career there in the acquisition and expression of its special skills and knowledge" (p3) [18]. According to Jones [19], quoting Stebbins [18], one of the six distinct qualities of serious leisure is the delivery of significant benefits to individual participants. The normal assumption is that these benefits outweigh the costs. However, Jones found that English professional football fans engaged with the sport as serious leisure but continuously participated in unrewarding activities [19]. Lamont, Kennelly and Moyle concluded that despite the costs and disappointment of event cancellations, serious ironman triathlon participants persisted with their careers as amateur athletes in this sport [20]. Previous research on outdoor activities has shown that well-being has a positive effect on participants' loyalty [21,22]. Thus, enhancing the well-being of sport fans could increase their loyalty.

Leisure activities play a buffering role against stress [23-25] and assist with the effective management of life stressors [26,27]. They have been found to reduce depression [28]; and enhance life satisfaction $[27,29,30]$ and well-being [31-34]. Researchers have demonstrated that increased levels of leisure involvement have a positive impact on well-being [35-38].

Empirical research on company employees suggests that organizational commitment is positively associated with well-being [39-41]. Likewise, serious leisure participants involved with professional sport may have high levels of organizational commitment to their favorite clubs and this can influence their well-being. Based on this assumption, the main goal of this research was to explore the influence of professional sport fans' leisure involvement on their well-being and to determine the mediating effect of organizational commitment. The specific research objectives were to:

1. Test the effect of leisure involvement on well-being.

2. Test the effect of leisure involvement on organizational commitment.

3. Test the effect of organizational commitment on well-being.

4. Examine the mediating role of organizational commitment between leisure involvement and well-being.

This research examined the causal relationships among these three variables to provide a reference for professional baseball teams in enhancing the well-being of their fans. Furthermore, the results could assist the sport agencies of governments of other Asian communities in promoting the sustainable development of professional baseball leagues. 


\section{Literature Review}

\subsection{Leisure Involvement and Well-Being}

The concept of involvement originated from psychology. Havitz and Dimanche consider involvement as "undetected motivation, incentive, or interest toward a certain leisure activity or related products, often elicited by a specific stimuli or situation." In other words, "leisure involvement refers to how we consider our leisure and how leisure influences our behavior" (p. 246) [42]. Therefore, to understand leisure involvement means to realize the leisure meaning for life and related leisure behavior.

Many scholars divide measurement methods of leisure involvement into behavioral and psychological involvement $[27,36,43]$. Behavioral involvement refers to the time and energy individuals put into specific activities [44], measured in terms of participation frequency, time spent, related resources available, etc. $[45,46]$. Psychological involvement refers to an individual's internal psychological process that prompts them to participate in leisure activities. Attraction, self-expression and centrality are the most widely used constructs for psychological involvement [43,47-49]. Attraction is the extent of a person's connection to a specific situation after being stimulated by an activity; the activity has importance and significance to the individual. Self-expression refers to a person's need to pursue self-realization, characterized by free self-expression and recognition for the activity, which prompts the individual to convince others to participate in the activity. Centrality refers to a person's lifestyle or social network, the degree of integration with the activity in which the individual participates and the central role the activity plays. In this research, the concept of McIntyre and Pigram was adopted to identify suitable leisure involvement-related questions. Attraction, self-expression and centrality served as the observed variables of leisure involvement [50].

Studies of well-being originated from three fields: mental health, quality of life and social gerontology [51]. Diener believes that subjective well-being positively reflects a person's overall life and consists of high life satisfaction and positive feelings, along with minimal negative feelings [52]. Diener, Emmons, Larsen and Griffin compiled the Satisfaction with Life Scale (SWLS), using assessments of overall life to measure the degree of life satisfaction [53]. Diener and Emmons used eight affective words to measure positive and negative affects [54]. Watson, Clark and Tellegen designed the Positive and Negative Affect Schedule (PANAS), including 20 questions each for the positive and negative dimensions [55]. Positive and negative affective responses and overall life satisfaction were adopted in this research to represent well-being.

Previous researchers have shown that when participating consistently in a specific activity, individuals experience less stress and a stronger sense of well-being [38,56,57]. In two studies of college students, it was concluded that leisure involvement had a positive effect on well-being [58,59]. A study of seniors showed that behavioral and socio-psychological involvement affected well-being [60]. Huang found that leisure involvement of serious leisure participants had a positive impact on well-being [61]. Huang also pointed out that leisure involvement of baseball fans had a positive influence on well-being [62]. Therefore, the first hypothesis of this research was:

Hypothesis 1. Leisure involvement has positive and significant effects on well-being.

\subsection{Serious Leisure}

Serious leisure has six distinguishing characteristics; perseverance, career, significant personal effort, durable benefits, unique ethos and tendency to identify strongly. Serious leisure participation is usually profound and long-lasting. Participants have strong skills, knowledge or experience with the activities and they generally get no remuneration $[63,64]$. They gain various social and personal benefits from the activities [65]. Sport fans usually have more knowledge and watch games in person, online or on TV. In general, they do not receive any remuneration but derive various benefits from the sport. Therefore, the researchers regard sport fans as serious leisure participants. 
Many studies have shown that well-being positively correlates with different kinds of leisure activities, including visiting family and friends, playing sport games, watching television and taking trips [66-68]. Cheng found that those engaged in serious leisure activities received the highest satisfaction, while casual leisure participants experienced moderate satisfaction [69]. Liu also reported greater well-being when participants were engaging in a serious and committed leisure activity [70]. Therefore, it appears that serious leisure participants usually derive a higher level of well-being.

Before leaving this discussion of serious leisure, some criticism of the concept must be noted and acknowledged. Veal, for example, assessed the serious leisure perspective (SLP) and challenged its status as a theory and a three-level typology (casual, serious and project-based leisure). He argued that SLP theory had been untested in forms other than serious leisure and that serious leisure was a continuum rather than being represented by three discrete categories [71].

\subsection{Organizational Commitment}

The concept of organizational commitment originated from the side-bet theory of Becker [72]. Robbins believes that organizational commitment is members' loyalty toward the organization, recognition for the organization and degree of participation in organizational events [73]. Some authors summarized previous research measurements of organizational commitment, dividing these into personal affection, perceived costs and risks and social relations into affective, continuance and normative commitment. Affective commitment is an individual's degree of attachment to an organization; continuance commitment refers to perceived costs and risks for leaving the existing organization; and normative commitment is a type of moral commitment, deeming organizational loyalty essential $[74,75]$. Some studies have used these three dimensions of organizational commitment developed by Allen and Meyer [74] to analyze work commitment [76] and consumer commitment [77]. Lee, Allen, Meyer and Rhee used the three dimensions to measure the organizational commitment of nurses and industrial hygiene technicians in South Korea [78].

Baseball spectating is a process that satisfies individuals' subjective feelings and stimulates their passion while creating a better quality of life [79]. When participants are involved in leisure activities, as time goes by, they become committed to leisure service providers [42,76,80,81]. Research by Kyle and Mowen showed that some variables of leisure involvement have a positive impact on organizational commitment [48]. The paper of $\mathrm{Wu}, \mathrm{Pan}$ and Huang indicated that if sport fans have more leisure involvement, they will have more commitment to the organization [82], thus, the second hypothesis was framed as:

Hypothesis 2. Leisure involvement has positive and significant effects on organizational commitment.

Organizational identification is a specific type of social identification [83]. However, the research is inconsistent on the relationship between organizational identity and commitment. Some suggest that organizational commitment is part of the organizational identity construct [84], whereas others consider organizational identity to be an element of organizational commitment [85]. Still other scholars believe that organizational identity leads to organizational commitment [86]. Ashforth and Mael argued that organizational commitment and identification are different but organizational identity is an important reference for organizational commitment [83]. Some past research has found organizational identification to be closely related to organizational commitment $[39,87]$. Stinglhamber et al. explored the relationship between employee organizational identity and affective organizational commitment [88]. The results showed organizational identification to be an antecedent of organizational commitment.

In sport fans' perceptions, organizational identification is close to team identification. Sport fans who highly identify with their teams, maintain memberships in related social networks and this enhances their social identity $[89,90]$. Wann, Melnick, Russell and Pease found that identification with a team was positively associated with personal self-esteem and positive emotions and was 
negatively correlated with depression and negative affection [91]. Team identification is associated with higher levels of social self-esteem [92,93] and more frequent positive emotions [94]. Wann [95] and Wann, Waddill, Polk and Weaver [96] found a positive relationship between sports team identification and well-being.

Panaccio and Vandenberghe explored the correlations among organizational support, organizational commitment (emotions, norms, perceived sacrificed leaving and perceived lack of alternatives) and subjective well-being perceived by members. Their findings showed that the higher the respondents' attachment to an organization, the greater their well-being [97]. Galais and Moser conducted a survey targeting temporary agency workers from 2000 to 2002. Temporary agency employees' commitment to the client organization had positive effects on individuals' well-being [98]. Jamal and Khan revealed there is a positive relationship between survivors' organizational commitment and psychological well-being after the downsizing process [41]. Harris and Cameron indicated that various dimensions of attachment to the organization (normative, affective, continuance commitment) are important positive predictors of the well-being of employees [39]. Hence, employees' organizational commitment positively influences their well-being. Sport fans' organizational identification positively affects their well-being. There are stronger relationships between organizational identification and organizational commitment. According to Stebbins' serious leisure concept, sport fans are regarded as serious leisure participants with career qualities [19]. Cuskelly, Harrington and Stebbins indicated that participants in serious leisure activities identify positively with the organization and have more commitment to it [99]. The study showed that organizational commitment of baseball fans has a positive impact on their well-being [82]. Therefore, this research examined the mediating effect of organizational commitment on the leisure involvement and well-being of sport fans. The third and fourth hypotheses were posited as follows:

Hypothesis 3. Organizational commitment has positive and significant effects on well-being.

Hypothesis 4. Organizational commitment mediates the influence of leisure involvement on well-being.

\section{Materials and Methods}

\subsection{Research Framework and Instrument}

Based on these four hypotheses, structural equation modeling was applied to determine the influential effects among leisure involvement, organizational commitment and well-being. The mediating effect of organizational commitment on leisure involvement and well-being was also measured.

Brother Elephants Baseball Team is one of the founding members of the CPBL. Since its foundation in 1990 through 2013, the team set the record for winning the Taiwan Series for three consecutive years, in 1992-1994 and 2001-2003 respectively, making it the first to have achieved three consecutive wins twice in the history of the League. Brother Elephants Baseball Team also has most fans in Taiwan. This team's fans were selected as the focus for this research. The conceptual model proposed is shown in Figure 1. 


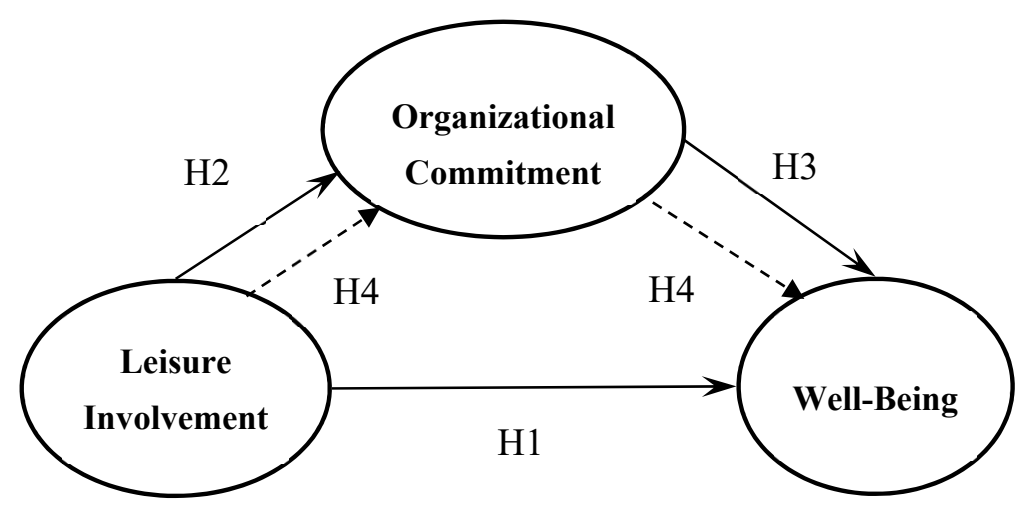

Figure 1. Conceptual Model. Note: $\longrightarrow$ Means directly affects $---\rightarrow$ Means indirectly affects.

Leisure involvement was defined as the affective input, motivation, excitement and other psychological states of a fan toward professional baseball games. The scales of McIntyre and Pigram [50] and Kyle et al. [43] were used. The contents included three dimensions: attraction, self-expression and centrality, consisting of 12 positive questions. A 5-point Likert scale $(1=$ strongly disagree to $5=$ strongly agree) was adopted for measurement.

Organizational commitment was defined as the identity of a fan's recognition, loyalty and participation toward a baseball team. The scale of Lee et al. [78] was used combining the dimensions of Meyer and Allen [75] and Meyer, Allen \& Smith [100]. The questions were then revised where appropriate to measure the organizational commitment toward Brother Elephants Baseball Team. Three dimensions, namely affective, continuance and normative commitment were included, with a total of 12 questions. A 7-point Likert scale $(1=$ strongly disagree to $7=$ strongly agree $)$ was applied.

Well-being was the fans' perceived emotions and life satisfaction. The SWLS scale of Diener et al. [53] and the questions of Diener and Emmons [54] served as references and revisions were made, including three dimensions, namely life satisfaction, positive affect and negative affect, consisting of 10 questions. A 7-point Likert scale ( $1=$ strongly disagree to $7=$ strongly agree) was applied. Thus, the higher the degree of life satisfaction and positive affect, the higher the well-being; the higher the perceived negative affect, the lower the well-being.

\subsection{Sampling and Research Tools}

The original questionnaire was in English and was translated into Chinese. To ensure that it was translated appropriately, the instrument was reviewed by six professors specializing in leisure, sport and tourism. Before conducting the survey, this research was approved by five professors (Review Committee) at the Graduate Institute of Sustainable Tourism and Recreation Management, National Taichung University of Education.

The researchers went to the stadium to survey the fans of Brother Elephants. Before administering the survey, interviewees were asked whether they were Brother Elephants' fans. Upon confirmation, respondents completed the questionnaires. The sampling method was purposive. The questionnaire was distributed before the break time in games, without unnecessarily disturbing the respondents. The sampling period was from 23 September to 23 October 2010. A total of 450 questionnaires were distributed and 406 valid copies were received, indicating a response rate of $90.2 \%$. The researchers did not offer any incentives to participate in the study. The average number of home game spectators for the Brother Elephants Team was 4730 in the past 20 years, which is the highest among the four teams. This is 1.35 times greater than the second team (LaNew).

The probability value of the questionnaire content validity was 0.83 . The Cronbach's alpha coefficient of leisure involvement was 0.921 and the Cronbach's alpha coefficient of organizational commitment was 0.955 . Well-being had Cronbach's alpha coefficient of 0.857 . All the reliability coefficients were at satisfactory levels. 


\subsection{Reliability and Validity Analysis}

Confirmatory Factor Analysis (CFA) was used to verify whether the observed variables could be used to measure the latent variables. The factor loading of all the questions of leisure involvement were between 0.56 and 0.86 ; the composition reliability (CR value) was 0.93 and the Average Variances Extracted (AVE) was 0.53 (Table 1). For organizational commitment, the factor loadings were between 0.66 and 0.92 ; the CR value was 0.95 and the AVE value was 0.63 (Table 2). For well-being, the factor loadings were between 0.63 and 0.94 ; the CR value was 0.96 and the AVE value was 0.72 (Table 3). Raines-Eudy pointed out that composite reliability values of over 0.5 were acceptable [101]. Fornell and Larcker believed that AVE values over 0.5 indicated that the scale possessed convergent validity [102].

Table 1. Statistical Analysis of Leisure Involvement.

\begin{tabular}{|c|c|c|c|c|c|}
\hline Variables and Dimensions & Mean & Standard Deviation & Factor Loading & CR & AVE \\
\hline Leisure Involvement & 3.99 & 0.58 & & 0.93 & 0.53 \\
\hline Attraction & 4.40 & 0.60 & & 0.88 & 0.65 \\
\hline $\begin{array}{l}\text { I am interested in watching } \\
\text { professional baseball. }\end{array}$ & 4.58 & 0.62 & 0.76 & & \\
\hline $\begin{array}{l}\text { It is important for me to watch } \\
\text { professional baseball. }\end{array}$ & 4.25 & 0.78 & 0.86 & & \\
\hline $\begin{array}{l}\text { To me, watching professional } \\
\text { baseball is one of the most } \\
\text { pleasurable things to do. }\end{array}$ & 4.46 & 0.65 & 0.74 & & \\
\hline $\begin{array}{l}\text { I really enjoy watching } \\
\text { professional baseball. }\end{array}$ & 4.45 & 0.71 & 0.84 & & \\
\hline Self-Expression & 4.01 & 0.64 & & 0.75 & 0.43 \\
\hline $\begin{array}{l}\text { Watching professional baseball } \\
\text { helps me relieve stress in life. }\end{array}$ & 4.28 & 0.75 & 0.68 & & \\
\hline $\begin{array}{l}\text { To me, watching professional } \\
\text { baseball allows me to truly } \\
\text { express myself. }\end{array}$ & 3.91 & 0.84 & 0.72 & & \\
\hline $\begin{array}{l}\text { I am mastering knowledge about } \\
\text { professional baseball watching. }\end{array}$ & 3.96 & 0.82 & 0.60 & & \\
\hline $\begin{array}{l}\text { I expect others to share the same } \\
\text { views on professional baseball } \\
\text { watching as mine. }\end{array}$ & 3.90 & 0.91 & 0.62 & & \\
\hline Centrality & 3.57 & 0.71 & & 0.82 & 0.53 \\
\hline $\begin{array}{l}\text { My life is centered on watching } \\
\text { professional baseball. }\end{array}$ & 3.45 & 0.99 & 0.82 & & \\
\hline $\begin{array}{l}\text { I met most of my friends through } \\
\text { professional baseball watching. }\end{array}$ & 2.74 & 0.99 & 0.56 & & \\
\hline $\begin{array}{l}\text { I am very willing to share } \\
\text { everything about professional } \\
\text { baseball watching with friends. }\end{array}$ & 4.00 & 0.79 & 0.71 & & \\
\hline $\begin{array}{l}\text { I derive higher satisfaction from } \\
\text { professional baseball watching } \\
\text { than I do in regular activities. }\end{array}$ & 3.85 & 0.93 & 0.79 & & \\
\hline
\end{tabular}


Table 2. Statistical Analysis of Organizational Commitment.

\begin{tabular}{|c|c|c|c|c|c|}
\hline Variables and Dimensions & Mean & Standard Deviation & Factor Loading & CR & AVE \\
\hline Organizational Commitment & 5.49 & 1.11 & & 0.95 & 0.63 \\
\hline Affective Commitment & 5.59 & 1.15 & & 0.92 & 0.70 \\
\hline $\begin{array}{l}\text { Problems faced by Brother } \\
\text { Elephants Baseball Team are like my } \\
\text { problems. }\end{array}$ & 4.98 & 1.48 & 0.66 & & \\
\hline $\begin{array}{l}\text { I feel a strong sense of } \\
\text { belongingness toward Brother } \\
\text { Elephants Baseball Team. }\end{array}$ & 5.87 & 1.25 & 0.89 & & \\
\hline $\begin{array}{l}\text { I have strong emotional attachment } \\
\text { to Brother Elephants Baseball Team. }\end{array}$ & 5.71 & 1.29 & 0.92 & & \\
\hline $\begin{array}{l}\text { Brother Elephants Baseball Team is } \\
\text { like family to me. }\end{array}$ & 5.54 & 1.33 & 0.86 & & \\
\hline $\begin{array}{l}\text { Brother Elephants Baseball Team } \\
\text { means a lot to me. }\end{array}$ & 5.87 & 1.24 & 0.85 & & \\
\hline Continuance Commitment & 5.57 & 1.17 & & 0.85 & 0.59 \\
\hline $\begin{array}{l}\text { If I don't support brother Elephants } \\
\text { Baseball Team, I may never be able } \\
\text { to find a team to support. }\end{array}$ & 5.86 & 1.43 & 0.68 & & \\
\hline $\begin{array}{l}\text { To me, the cost of not supporting } \\
\text { Brother Elephants Baseball Team is } \\
\text { far higher than the benefits. }\end{array}$ & 5.02 & 1.48 & 0.72 & & \\
\hline $\begin{array}{l}\text { I will not stop supporting Brother } \\
\text { Elephants Baseball Team; otherwise, } \\
\text { I might lose my stand. }\end{array}$ & 5.64 & 1.42 & 0.85 & & \\
\hline $\begin{array}{l}\text { My life will be affected if I decide to } \\
\text { no longer support Brother } \\
\text { Elephants Baseball Team. }\end{array}$ & 4.97 & 1.66 & 0.81 & & \\
\hline Normative Commitment & 5.30 & 1.25 & & 0.79 & 0.56 \\
\hline $\begin{array}{l}\text { I feel obligated to continue } \\
\text { supporting Brother Elephants } \\
\text { Baseball Team. }\end{array}$ & 5.63 & 1.45 & 0.82 & & \\
\hline $\begin{array}{l}\text { Even if there is a better baseball } \\
\text { team to choose. I will still support } \\
\text { Brother Elephants Baseball Team. }\end{array}$ & 6.04 & 1.28 & 0.71 & & \\
\hline $\begin{array}{l}\text { If I stop supporting Brother } \\
\text { Elephants Baseball Team, I am a } \\
\text { person with no credibility. }\end{array}$ & 4.35 & 1.84 & 0.71 & & \\
\hline
\end{tabular}


Table 3. Statistical Analysis of Well-Being.

\begin{tabular}{|c|c|c|c|c|c|}
\hline Variables and Dimensions & Mean & Standard Deviation & Factor Loading & CR & AVE \\
\hline Well-Being & 4.95 & 0.85 & & 0.96 & 0.72 \\
\hline Life Satisfaction & 4.78 & 1.10 & & 0.87 & 0.63 \\
\hline $\begin{array}{l}\text { In general, my life is close to my } \\
\text { ideal. }\end{array}$ & 4.96 & 1.20 & 0.77 & & \\
\hline My living condition is good. & 5.41 & 1.09 & 0.83 & & \\
\hline I am quite satisfied with my life. & 5.16 & 1.20 & 0.91 & & \\
\hline $\begin{array}{l}\text { So far, I have acquired things } \\
\text { important to me in my life. }\end{array}$ & 4.40 & 1.63 & 0.63 & & \\
\hline Positive Affect & 5.49 & 1.02 & & 0.94 & 0.84 \\
\hline I feel pleasurable & 5.54 & 1.05 & 0.91 & & \\
\hline I feel satisfied & 5.42 & 1.13 & 0.94 & & \\
\hline I feel enjoyable & 5.45 & 1.08 & 0.91 & & \\
\hline Negative Affect & 3.41 & 1.43 & & 0.90 & 0.74 \\
\hline I feel depressed & 3.42 & 1.34 & 0.84 & & \\
\hline I feel angry & 3.24 & 1.50 & 0.87 & & \\
\hline I feel worried & 3.67 & 1.29 & 0.87 & & \\
\hline
\end{tabular}

\section{Results}

Among the research participants, $66.2 \%$ were males, $33.8 \%$ were female and $57.9 \%$ were aged 21-30. Most of the respondents (51.2\%) had university educations. The highest proportions were whose length of time engaged in baseball watching was 6-10 years (33.8\%) and who had been supporting Brother Elephants Baseball League for 6-10 years (33.3\%).

\subsection{Test of Hypothesis 1}

The researchers determined whether leisure involvement had a positive effect on well-being. The statistics for goodness of fit were $\chi^{2}=28.50(p=0.00)$, Goodness of Fit Index $(\mathrm{GFI})=0.98$, Adjusted Goodness of Fit Index $(\mathrm{AGFI})=0.94$, Standardized Root Mean Square Residual $(\mathrm{SRMR})=0.04$, Root Mean Square Error of Approximation $($ RMSEA) $=0.08$, Non-normed Fit Index $(N N F I)=0.96$, Comparative Fit Index $(\mathrm{CFI})=0.98, \chi^{2} / \mathrm{df}=3.56$. It was concluded that the proposed model had a good fit (Table 4). According to the path analysis results, the direct effect of baseball fans' leisure involvement on their well-being was significant, accounting for $0.47(p<0.01)$ (Figure 2$)$. The relationship of leisure involvement to well-being was positive and significant. Thus, Hypothesis 1 was supported.

Table 4. Goodness-of-fit Test for Leisure Involvement and Well-Being.

\begin{tabular}{ccc}
\hline Indices & Model fit & Criteria \\
\hline$\chi^{2} / \mathrm{df}$ & 3.56 & \\
GFI & 0.98 & $>0.90$ \\
AGFI & 0.94 & $>0.90$ \\
SRMR & 0.04 & $<0.05$ \\
RMSEA & 0.08 & $<0.08$ \\
NNFI & 0.96 & $>0.90$ \\
CFI & 0.98 & $>0.90$ \\
\hline
\end{tabular}




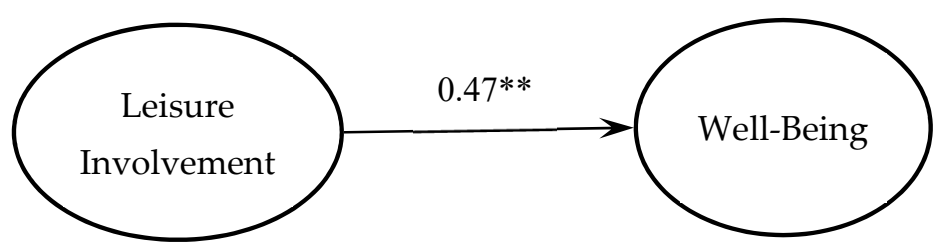

Figure 2. The effect of leisure involvement on well-being. Note: ${ }^{* *} p<0.01$.

\subsection{Tests of Hypotheses 2 and 3}

The relationships among leisure involvement, organizational commitment and well-being were examined. A mediating model was developed (Figure 3). The fit statistics of the model were as follows: $\chi^{2}=88.21(p=0.00), \mathrm{GFI}=0.95, \mathrm{AGFI}=0.91, \mathrm{SRMR}=0.04, \mathrm{RMSEA}=0.08, \mathrm{NNFI}=0.97, \mathrm{CFI}=0.98$ and $\chi^{2} / \mathrm{df}=3.70$. Overall, the mediating model had good fit (Table 5). Moreover, the path analysis results showed that the direct effect of leisure involvement on organizational commitment was positive and significant at $0.77(p<0.01)$ and the direct effect of organizational commitment on well-being was positive and significant at $0.39(p<0.01)$. In other words, the higher fans' leisure involvement, the higher was their organizational commitment; the higher fans' organizational commitment, the higher was their well-being. Thus, Hypothesis 2 and 3 were supported. It was found that leisure involvement indirectly affected well-being through organizational commitment, the indirect effect was $0.30(0.77 \times 0.39)$ $(p<0.01)$.

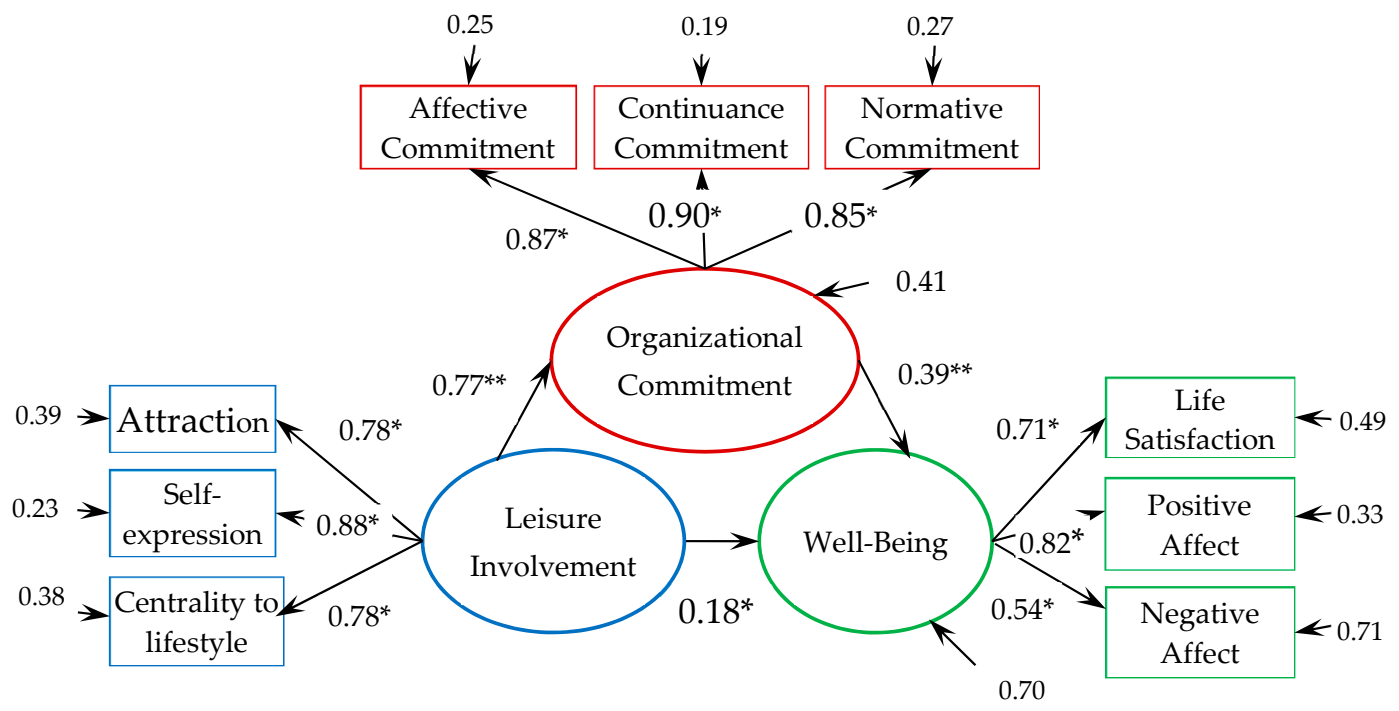

Figure 3. The test for the mediating model of organizational commitment. Note: ${ }^{*} p<0.01 * p<0.05$.

Table 5. Goodness-of-fit Test for the Mediating Model.

\begin{tabular}{ccc}
\hline Indices & Model Fit & Criteria \\
\hline$\chi^{2} / \mathrm{df}$ & 3.70 & \\
GFI & 0.95 & $>0.90$ \\
AGFI & 0.91 & $>0.90$ \\
SRMR & 0.04 & $<0.05$ \\
RMSEA & 0.08 & $<0.08$ \\
NNFI & 0.97 & $>0.90$ \\
CFI & 0.98 & $>0.90$ \\
\hline
\end{tabular}




\subsection{Test of Hypothesis 4}

Fans' leisure involvement had a positive and significant effect on well-being, with a direct effect of $0.47(p<0.01)$ (Figure 2). When organizational commitment was included in the model (Figure 3), leisure involvement also had a significant effect on well-being but with a weak direct effect of 0.18 $(p<0.05)$. In the mediating model, leisure involvement had a significant effect on well-being through organizational commitment and the indirect effect was 0.30 . Thus, the total effect of leisure involvement on well-being was $0.48(0.18+0.30)$. The indirect effect value of leisure involvement through the effect of organizational commitment accounted for $62.5 \%$ of the total effects $(0.30 / 0.48)$, thus indicating organizational commitment is a mediating variable of leisure involvement and well-being. Thus, for Hypothesis 4, organizational commitment partially mediated the influence of leisure involvement on well-being and it was supported.

The findings showed that the Brother Elephants Team fans' performance was above average in three respects: leisure involvement, organizational commitment and well-being. The average value of the leisure involvement was 3.99 and the standard deviation was 0.58 , thus indicating these baseball fans' positive leisure involvement. The concept with the most profound leisure involvement was attraction, with an average value of 4.40 , followed by self-expression (4.01) and centrality (3.57) (Table 1 ). The average value of overall organizational commitment was 5.49 with a standard deviation of 1.11. The concept with the highest value was affective commitment at 5.59. Continuance commitment followed with the value of 5.57. Finally, normative commitment had an average value of 5.30 (Table 2). For well-being, the overall average value was 4.95 with a standard deviation of 0.85 . The concept with the highest average value was positive affect (5.49), followed by life satisfaction (4.78) and negative affect (3.41) (Table 3).

The results indicated that attraction, self-expression and centrality were representations of sport fans' leisure involvement, of which self-expression had the highest factor load (0.88), followed by attraction (0.78) and centrality (0.78). The organizational commitment of baseball fans can be reflected in affective, continuance and normative commitment, of which continuance commitment had the highest factor load (0.90), followed by affective commitment $(0.87)$ and normative commitment $(0.85)$. As for well-being, it was reflected by life satisfaction, positive affect and negative affect, of which positive affect had the highest factor load (0.82), followed by life satisfaction (0.71) and negative affect (0.54).

\section{Discussion}

The overall goal of this research was to explore the influence of the leisure involvement of sport fans on their well-being and the mediating effect of organizational commitment. The findings revealed that the leisure involvement of baseball fans has a positive impact on their well-being. This finding coincides with the research results of Lu and Hu [59], Dai et al. [103], Huang [62] and Doerksen et al. [58]. Huang indicated the leisure involvement of sport volunteers had a positive impact on their well-being [62]. Doerksen et al. not only suggested that leisure activity related to well-being but also indicated that participating in specific activities (including social activities and volunteering) readily enhanced well-being [58]. This analysis found that the leisure involvement of sport fans positively influenced their well-being.

In this research, the sport fans with career-like qualities were assumed to be serious leisure participants. Related studies of enterprises found that the higher the employees' organizational commitment, the higher the level of their well-being. Hence, the mediating effect of organizational commitment on sport fans' leisure involvement and well-being was explored. Indeed, the results confirmed that organizational commitment possesses a partial mediating effect. The sport fans with higher leisure involvement had higher organizational commitment. In other words, the higher the involvement of the fans in watching baseball games, the more likely it was for them to develop commitment to the baseball team. This result is comparable to previous research findings $[48,80,81]$. When the fans developed commitment to the baseball team they support, it 
enhanced their well-being, as confirmed in previous studies $[39,41,97,98]$. Some previous studies found organizational commitment to be an important positive predictor of the well-being of employees $[39,41,98]$. This research investigated the effect of organizational commitment on the well-being of sport fans and showed that organizational commitment was also a positive predictor of fan well-being. Additionally, it demonstrated that the most effective way to promote well-being is by simultaneously increasing fans' leisure involvement and their organizational commitment. Since community well-being interacts with community development [18], increasing the well-being of sport fans will enhance community well-being and community development in teams' locations.

\section{Conclusions and Implications}

\subsection{Conclusions}

This research explored the relationship between the leisure involvement and well-being of baseball fans. The results are exploratory and provide initial support for the mediating role of organizational commitment for sport fans. The leisure involvement of baseball fans had a positive impact on their well-being and organizational commitment partially mediated between leisure involvement and well-being.

Leisure involvement positively and significantly affected organizational commitment. That is, the greater the extent of baseball fans' involvement in the leisure activity, the more likely it is for them to accumulate commitment to the baseball team. Furthermore, organizational commitment also positively and significantly affected their well-being. When baseball fans are committed to the sport team organization, their perceived emotions and life satisfaction are affected. Finally, leisure involvement positively and significantly affects well-being, while organizational commitment enhances the effect of leisure involvement on well-being.

These findings indicate that for baseball fans to enhance their well-being, in addition to their involvement in watching professional baseball games (leisure involvement); they must also have a commitment with the ball team organization to attain a higher-level well-being. The findings showed that the baseball fans' performance was above average regarding leisure involvement, organizational commitment and well-being. Among the leisure involvement variables, attraction was the highest, while centrality was the lowest. In organizational commitment, affective commitment was highest, while normative commitment was the lowest. For well-being, positive affect was higher, while negative affect was lower. After revising the model, it was found that the three dimensions of attraction, self-expression and centrality sufficed as representations of the baseball fans' leisure involvement. Among them, the reflection of self-expression was more evident than attraction and centrality. Affective, continuance and normative commitment were representative of the baseball fans' commitment to the baseball team organization. In particular, continuance commitment reflected more evident effects compared to affective commitment and normative commitment. Life satisfaction, positive affect and negative affect represented baseball fans' well-being, of which positive affect showed the highest reflection, followed by life satisfaction and negative affect.

There is insufficient research on the relationships among sport fans' leisure involvement, organizational commitment and well-being. This study regards fans as serious leisure participants to understand the impact of their leisure involvement on well-being. Because of serious leisure participants have career characteristics, this research explored whether organizational commitment mediates the influence of leisure involvement on well-being. The results showed that the fans' leisure involvement will affect the sense of well-being and organizational commitment partially mediates the influence of leisure involvement on well-being. This study extends the previous research and uses the concept of organizational commitment to explore the relationships for sport fans among leisure involvement, organizational commitment and well-being. Sport organizations may benefit from the enhancement of sport fans' well-being. Furthermore, increasing sport fans' well-being may improve sport community well-being and community development. 


\subsection{Implications, Limitations and Future Research Directions}

Professional sport promotion not only encourages the public to take part in such activities. Also, if participation in spectating activities promotes people's psychological satisfaction (well-being), the activities are said to be worthy of receiving promotion. The results showed that leisure involvement and organizational commitment are influential in enhancing baseball fans' well-being, Therefore, to increase fans' well-being, in addition to attracting sport fans to more frequently watch games, proper sport fan management is a strategic option. These initiatives include organizing sport fan gatherings to share baseball knowledge, making friends, exchanging ideas after watching games, giving baseball fans face-to-face encounters with players, to link living, friend-making and baseball-spectating. Baseball fans often choose to continue to support a baseball team because the main players stay on the side. It is suggested that baseball teams sign multi-year contracts with players to ensure fans continue to be supportive of the team. To have "hot" game topics to discuss and make games worth watching, baseball teams may recruit domestic and foreign professionals who are experienced in international games. Furthermore, territorialism, court adoption and so on may be increased to strengthen audience cohesion and foster fan commitment to the team. Once the relationship is strengthened, well-being will improve as well.

This research only sampled the sport fans of Taiwan's Brother Elephants' Baseball Team as the subjects. Although the research results had good reliability and validity, this does not mean that different samples still possess stable results or can be used to make inferences on the fans of other baseball teams. Thus, it is recommended that the fans of other baseball teams be targeted as research participants in future studies to further test the applicability of "the sport fans' model of leisure involvement, organizational commitment and well-being." Furthermore, it is suggested that sport fans for other sports be targeted for surveys, such as professional basketball, soccer and American football, to examine the validity extension of the model. While most of the literature discusses the relationship between two of the above three constructs [41,48,58,59], integrating all three constructs for a Professional Baseball League has not yet been attempted. This study of Asian perspectives might be considered as a pioneering research effort. The findings show that organizational commitment indeed affects sport fans' well-being. Therefore, it is advisable that future studies explore the effect of enterprise organizational influential factors, such as organizational identification, organizational loyalty and so on, on the well-being of sport fans.

The authors also acknowledge that there are other variables influencing sport fans' commitment and loyalty to specific clubs and that significant related research exists but was not extensively covered in this analysis. Some of these variables can be controlled by the professional sport club management and others cannot. These include, among others, branded online communities [104]; fan club membership [105]; and corporate social responsibility (CSR) [106].

Acknowledgments: This article is based on a paper presented at the 13th ApacCHRIE Conference in conjunction with 14th Asia Pacific Forum Conference. Thanks for the comments from reviewers and audience of the conference. Part of this research was supported by the National Science Council (now Ministry of Science and Technology) of Taiwan, under project number NSC 100-2628-H-142-003 and NSC 99-2410-H-142-025-SSS.

Author Contributions: Su-lan Pan revised the introduction, literature review, discussion and performed statistical analysis. Homer $\mathrm{C}$. $\mathrm{Wu}$ is the supervisor of this project and proposed the idea of the research framework. Alastair M. Morrison revised the discussion and wrote the conclusion. He also coordinated the whole manuscript. Min-Tzu Huang developed the instruments, collected the data and wrote the results. Wen-Shiung Huang participated in the research discussion and offered statistical advice.

Conflicts of Interest: The authors declare no conflict of interest. 


\section{References}

1. League, C.P.B. Brief History of CPBL. Available online: http:/ /www.cpbl.com.tw/eng/history (accessed on 19 January 2018).

2. Dwyer, B.; Greenhalgh, G.P.; LeCrom, C.W. Exploring fan behavior: Developing a scale to measure sport eFANgelism. J. Sport Manag. 2015, 29, 642-656. [CrossRef]

3. Wang, R.T.; Zhang, J.J.; Tsuji, Y. Examining fan motives and loyalty for the Chinese Professional Baseball League of Taiwan. Sport Manag. Rev. 2011, 14, 347-360. [CrossRef]

4. Wang, M.C.H.; Tang, Y.Y. Examining the antecedents of sport team brand equity: A dual-identification perspective. Sport Manag. Rev. 2017. [CrossRef]

5. Bauer, H.H.; Stokburger-Sauer, N.E.; Exler, S. Brand image and fan loyalty in professional team sport: A refined model and empirical assessment. J. Sport Manag. 2008, 22, 205-226. [CrossRef]

6. Bee, C.C.; Havitz, M.E. Exploring the relationship between involvement, fan attraction, psychological commitment and behavioural loyalty in a sports spectator context. Int. J. Sports Mark. Spons. 2010, 11, 140-157. [CrossRef]

7. Dwyer, B. Divided loyalty? An analysis of fantasy football involvement and fan loyalty to individual National Football League (NFL) teams. J. Sport Manag. 2011, 25, 445-457. [CrossRef]

8. Funk, D.C.; James, J.D. Consumer loyalty: The meaning of attachment in the development of sport team allegiance. J. Sport Manag. 2006, 20, 189-217. [CrossRef]

9. Stevens, S.; Rosenberger, P.J. The influence of involvement, following sport and fan identification on fan loyalty: An Australian perspective. Int. J. Sports Mark. Spons. 2012, 13, 57-71. [CrossRef]

10. Yoshida, M.; Heere, B.; Gordon, B. Predicting behavioral loyalty through community: Why other fans are more important than our own intentions, our satisfaction, and the team itself. J. Sport Manag. 2015, 29, 318-333. [CrossRef]

11. Chavanat, N.; Martinent, G.; Ferrand, A. Sponsor and sponsees interactions: Effects on consumers' perceptions of brand image, brand attachment, and purchasing intention. J. Sport Manag. 2009, 23, 644-670. [CrossRef]

12. Hong, J. Sport fans' sponsorship evaluation based on their perceived relationship value with a sport property. Int. J. Sport Manag. Mark. 2011, 9, 116-131. [CrossRef]

13. Schlesinger, T.; Güngerich, M. Analysing sport sponsorship effectiveness-The influence of fan identification, credibility and product-involvement. Int. J. Sport Manag. Mark. 2011, 9, 54-74. [CrossRef]

14. Deci, E.L.; Ryan, R.M. Intrinsic Motivation and Self-Determination in Human Behavior; Plenum Press: New York, NY, USA, 1985; p. 371.

15. Chiu, C.M.; Cheng, H.L.; Huang, H.Y.; Chen, C.F. Exploring individuals' subjective well-being and loyalty towards social network sites from the perspective of network externalities: The Facebook case. Int. J. Inf. Manag. 2013, 33, 539-552. [CrossRef]

16. Morris, E.A. Should we all just stay home? Travel, out-of-home activities, and life satisfaction. Transp. Res. Part A 2015, 78, 519-536. [CrossRef]

17. Lee, S.J.; Kim, Y.; Phillips, R. Exploring the Intersection of Community Well-Being and Community Development. In Community Well-Being and Community Development: Conceptions and Applications; Lee, S.J., Kim, Y., Phillips, R., Eds.; Springer International Publishing: Cham, Switzerland, 2015; pp. 1-7.

18. Stebbins, R.A. Amateurs, Professionals and Serious Leisure; McGill Queen's University Press: Montreal, QC, Canada, 1992.

19. Jones, I. A model of serious leisure identification: The case of football fandom. Leis. Stud. 2000, 19, $283-298$. [CrossRef]

20. Lamont, M.; Kennelly, M.; Moyle, B. Costs and perseverance in serious leisure careers. Leis. Sci. 2014, 36, 144-160. [CrossRef]

21. Lee, D.J.; Kruger, S.; Whang, M.J.; Uysal, M.; Sirgy, M.J. Validating a customer well-being index related to natural wildlife tourism. Tour. Manag. 2014, 45, 171-180. [CrossRef]

22. Okello, M.M.; Yerian, S. Tourist satisfaction in relation to attractions and implications for conservation in the protected areas of the Northern Circuit, Tanzania. J. Sustain. Tour. 2009, 17, 605-625. [CrossRef]

23. Coleman, D. Leisure based social support, leisure dispositions and health. J. Leis. Res. 1993, 25, 350-361. [CrossRef] 
24. Winefield, A.H.; Tiggemann, M.; Winefield, H.R. Spare time use and psychological well-being in employed and unemployed young people. J. Occup. Organ. Psychol. 1992, 65, 307-313. [CrossRef]

25. Frey, B.S.; Stutzer, A. Happiness and Economics; Princeton University Press: Princeton, NJ, USA, 2002.

26. Kim, J.; Kim, M.; Henderson, K.A.; Han, A.; Park, S.H. Serious engagement in sport and health benefits among Korean immigrants in the USA. Int. J. Qual. Studies Health Well-Being 2016, 11. [CrossRef] [PubMed]

27. Heo, J.; Stebbins, R.; Kim, J.; Lee, I. Serious Leisure, Life Satisfaction, and Health of Older Adults. Leis. Sci. 2013, 35, 16-32. [CrossRef]

28. Ku, P.W.; Fox, K.R.; Chen, L.J.; Chou, P. Physical activity and depressive symptoms in older adults: 11-year follow-up. Am. J. Prev. Med. 2012, 42, 355-362. [CrossRef] [PubMed]

29. Griffin, J.; McKenna, K. Influences on leisure and life satisfaction of elderly people. Phys. Occup. Ther. Geriatr. 1999, 15, 1-16. [CrossRef]

30. Nimrod, G. Expanding, reducing, concentrating and diffusing: Post retirement leisure behavior and life satisfaction. Leis. Sci. 2007, 29, 91-111. [CrossRef]

31. Brajsa-Zganec, A.; Merkas, M.; Sverko, I. Quality of life and leisure activities: How do leisure activities contribute to subjective well-being? Soc. Indic. Res. 2011, 102, 81-91. [CrossRef]

32. Hughes-Hassell, S.; Rodge, P. The leisure reading habits of urban adolescents. J. Adolesc. Adult Lit. 2007, 51, 22-33. [CrossRef]

33. Lloyd, K.; Little, D.E. Self-determination theory as a framework for understanding women's psychological well-being outcomes from leisure-time physical activity. Leis. Sci. 2010, 32, 369-385. [CrossRef]

34. Sacker, A.; Cable, N. Do adolescent leisure-time physical activities foster health and well-being in adulthood? Evidence from two British birth cohorts. Eur. J. Public Health 2006, 16, 332-336. [CrossRef] [PubMed]

35. Godbey, G. Leisure in Your Life: An Exploration, 6th ed.; Venture Pub: State College, PA, USA, 2003 ; p. 417.

36. Havitz, M.E.; Mannell, R.C. Enduring involvement, situational involvement, and flow in leisure and non-leisure activities. J. Leis. Res. 2005, 37, 152-177. [CrossRef]

37. Yang, W.C.; Chen, K.C.; Hsueh, Y.S.; Tan, C.P.; Chang, C.M. The relationship between leisure and well-being in Taiwanese college students. Soc. Behav. Personal. 2012, 40, 1245-1254. [CrossRef]

38. Coghlan, A.; Filo, K. Bringing personal character strengths into the production of the leisure experience. Leis. Sci. 2016, 38, 100-117. [CrossRef]

39. Harris, G.E.; Cameron, J.E. Multiple dimensions of organizational identification and commitment as predictors of turnover intentions and psychological well-being. Can. J. Behav. Sci. 2005, 37, 159-169. [CrossRef]

40. Burgess, J.; Harrison, C.M.; Filius, P. Environmental communication and the cultural politics of environmental citizenship. Environ. Plan. A 1998, 30, 1445-1460. [CrossRef]

41. Jamal, F.Q.; Khan, A.M. Association of downsizing with survivor's organizational commitment, work motivation and psychological well-being in secondary and tertiary sectors of economy of Pakistan. J. Behav. Sci. 2013, 23, 1-25.

42. Havitz, M.E.; Dimanche, F. Leisure involvement revisited: Conceptual conundrums and measurement advances. J. Leis. Res. 1997, 29, 245-278. [CrossRef]

43. Kyle, G.; Graefe, A.; Manning, R.; Bacon, J. An examination of the relationship between leisure activity involvement and place attachment among hikers along the Appalachian Trail. J. Leis. Res. 2003, 35, 249-273. [CrossRef]

44. Stone, R.N. The Marketing Characteristics of Involvement. Adv. Consum. Res. 1984, 11, 210-215.

45. Csikszentmihalyi, M. Beyond Boredom and Anxiety; Jossey-Bass: San Francisco, CA, USA, 2000.

46. Kim, S.S.; Scott, D.; Crompton, J.L. An exploration of the relationships among social psychological involvement, behavioral involvement, commitment, and future intentions in the context of birdwatching. J. Leis. Res. 1997, 29, 320-341. [CrossRef]

47. McIntyre, N. The personal meaning of participation: Enduring involvement. J. Leis. Res. 1989, 21, 167-179. [CrossRef]

48. Kyle, G.T.; Mowen, A.J. An examination of the leisure involvement-Agency commitment relationship. J. Leis. Res. 2005, 37, 342-363. [CrossRef]

49. Wiley, C.G.E.; Shaw, S.M.; Havitz, M.E. Men's and women's involvement in sports: An examination of the gendered aspects of leisure involvement. Leis. Sci. 2000, 22, 19-31. 
50. McIntyre, N.; Pigram, J.J. Recreation specialization reexamined: The case of vehicle-based campers. Leis. Sci. 1992, 14, 3-15. [CrossRef]

51. Robinson, J.P.; Shaver, P.R.; Wrightsman, L.S.; Andrews, F.M. Measures of Personality and Social Psychological Attitudes; Academic Press: San Diego, CA, USA, 1991.

52. Diener, E. Subjective well-being. Psychol. Bull. 1984, 95, 542-575. [CrossRef] [PubMed]

53. Diener, E.D.; Emmons, R.A.; Larsen, R.J.; Griffin, S. The satisfaction with life scale. J. Personal. Assess. 1985, 49, 71-75. [CrossRef] [PubMed]

54. Diener, E.; Emmons, R.A. The independence of positive and negative affect. J. Personal. Soc. Psychol. 1984, 47, 1105-1117. [CrossRef]

55. Watson, D.; Clark, L.A.; Tellegen, A. Development and validation of brief measures of positive and negative affect: The PANAS scales. J. Personal. Soc. Psychol. 1988, 54, 1063-1070. [CrossRef]

56. Fredricks, J.A.; Eccles, J.S. Is extracurricular participation associated with beneficial outcomes? Concurrent and longitudinal relations. Dev. Psychol. 2006, 42, 698-713. [CrossRef] [PubMed]

57. Ruuskanen, J.M.; Ruoppila, I. Physical activity and psychological well-being among people aged 65 to 84 years. Age Ageing 1995, 24, 292-296. [CrossRef] [PubMed]

58. Doerksen, S.E.; Elavsky, S.; Rebar, A.L.; Conroy, D.E. Weekly Fluctuations in College Student Leisure Activities and Well-Being. Leis. Sci. 2014, 36, 14-34. [CrossRef]

59. Lu, L.; Hu, C.H. Personality, leisure experiences and happiness. J. Happiness Stud. 2005, 6, 325-342. [CrossRef]

60. Beck, S.H.; Page, J.W. Involvement in activities and the psychological well-being of retired men. Act. Adapt. Aging 1988, 11, 31-47. [CrossRef]

61. Huang, Y.T. A study on the relationships between leisure activity involvement, well-being, the benefits of serious leisure activity, and sports volunteer self-actualization in the Changhua National Games. J. Hum. Resour. Adult Learn. 2013, 9, 12-25.

62. Huang, M.T. Research on the Relationships among Chinese Professional Baseball League Fans' Leisure Involvement, Organizational Commitment and Well-Being: A Case of the Brother Elephants Club. Unpublished Master's Thesis, National Taichung University of Education, Taichung, Taiwan, 2011.

63. Stebbins, R.A. Serious Leisure. Society 2001, 38, 53-57. [CrossRef]

64. Stebbins, R.A. Serious Leisure: A Perspective for Our Time; Transaction Publishers: New Brunswick, NJ, USA, 2008.

65. Stebbins, R.A.; Elkington, S. The Serious Leisure Perspective: An Introduction; Routledge: Milton Park, Abingdon, UK, 2014.

66. Mitas, O. Positive Emotions in Mature Adults' Leisure Travel Experiences. Ph.D. Thesis, Pennsylvania State University, State College, PA, USA, 2010.

67. Menec, V.H.; Chipperfield, J.G. Remaining active in later life: The role of locus of control in seniors' leisure activity participation, health, and life satisfaction. J. Aging Health 1997, 9, 105-125. [CrossRef] [PubMed]

68. Yarnal, C.M.; Chick, G.; Kerstetter, D.L. I did not have time to play growing up ... so this is my play time. It's the best thing I have ever done for myself: What is play to older women? Leis. Sci. 2008, 30, 235-252. [CrossRef]

69. Cheng, H.P. Serious Leisure, Leisure Satisfaction and Gardening by Older Adults. Ph.D. Thesis, University of Queensland, Brisbane, Australia, 2010.

70. Liu, H. Personality, leisure satisfaction, and subjective well-being of serious leisure participants. Soc. Behav. Personal. 2014, 42, 1117-1125. [CrossRef]

71. Veal, A.J. The serious leisure perspective and the experience of leisure. Leis. Sci. 2017, 39, 205-223. [CrossRef]

72. Becker, H.S. Notes on the concept of commitment. Am. J. Sociol. 1960, 66, 32-40. [CrossRef]

73. Robbins, S.P. Organizational Behavior: Concepts, Controversies, and Applications; Prentice Hall: Tornto, ON, Canada, 2001.

74. Allen, N.J.; Meyer, J.P. The measurement and antecedents of affective, continuance and normative commitment to the organization. J. Occup. Organ. Psychol. 1990, 63, 1-18. [CrossRef]

75. Meyer, J.P.; Allen, N.J. Commitment in the Workplace: Theory, Research, and Application; Sage Publications: Thousand Oaks, CA, USA, 1997.

76. Meyer, J.P.; Herscovitch, L. Commitment in the workplace: Toward a general model. Hum. Resour. Manag. Rev. 2001, 11, 299-326. [CrossRef] 
77. Vandenberghe, C.; Bentein, K.; Michon, R.; Chebat, J.C.; Tremblay, M.; Fils, J.F. An examination of the role of perceived support and employee commitment in employee-customer encounters. J. Appl. Psychol. 2007, 92, 1177-1187. [CrossRef] [PubMed]

78. Lee, K.; Allen, N.J.; Meyer, J.P.; Rhee, K.Y. The three-component model of organisational commitment: An application to South Korea. Appl. Psychol. 2001, 50, 596-614. [CrossRef]

79. Plunkett, J.W. Plunkett's Sports Industry Almanac 2008: Sports Industry Market. Research, Statistics, Trends $\mathcal{E}$ Leading Companies, 2008 ed.; Plunkett Research: Houston, TX, USA, 2007; p. 490.

80. Iwasaki, Y.; Havitz, M.E. A path analytic model of the relationships between involvement, psychological commitment, and loyalty. J. Leis. Res. 1998, 30, 256-280. [CrossRef]

81. Iwasaki, Y.; Havitz, M.E. Examining relationships between leisure involvement, psychological commitment and loyalty to a recreation agency. J. Leis. Res. 2004, 36, 45-72. [CrossRef]

82. Wu, H.C.; Pan, S.L.; Huang, M.T. A study of the relationship among leisure involvement, organizational commitment, and well-being: Viewpoints from fans of a professional baseball team in Taiwan. Presented at the 13th APacCHRIE Conference in conjunction with 14th Asia Pacific Forum Conference, Auckland, New Zealand, 10-13 June 2015.

83. Ashforth, B.E.; Mael, F. Social identity theory and the organization. Acad. Manag. Rev. 1989, 14, $20-39$.

84. Ellemers, N.; De Gilder, D.; Haslam, S.A. Motivating individuals and groups at work: A social identity perspective on leadership and group performance. Acad. Manag. Rev. 2004, 29, 459-478.

85. O'Reilly, C.A.; Chatman, J. Organizational commitment and psychological attachment: The effects of compliance, identification, and internalization on prosocial behavior. J. Appl. Psychol. 1986, 71, 492-499. [CrossRef]

86. Meyer, J.P.; Becker, T.E. Vandenberghe, C. Employee commitment and motivation: A conceptual analysis and integrative model. J. Appl. Psychol. 2004, 89, 991-1007. [CrossRef] [PubMed]

87. Mael, F.A.; Tetrick, L.E. Identifying organizational identification. Educ. Psychol. Meas. 1992, 52, 813-824. [CrossRef]

88. Stinglhamber, F.; Marique, G.; Caesens, G.; Desmette, D.; Hansez, I.; Hanin, D.; Bertrand, F. Employees' organizational identification and affective organizational commitment: An integrative approach. PLoS ONE 2015, 10. [CrossRef] [PubMed]

89. Abrams, D.E.; Hogg, M.A. Social motivation, self-esteem, and social identity. In Social Identity Theory: Constructive and Critical Advances; Springer-Verlag Publishing: New York, NY, USA, 1990.

90. Wann, D.; Pierce, S. Measuring Sport Team Identification and Commitment: An Empirical Comparison of the Sport Spectator Identification Scale and the Psychological Commitment to Team Scale. N. Am. J. Psychol. 2003, 5, 365-372.

91. Wann, D.L.; Melnick, M.J.; Russell, G.W.; Pease, D.G. Sport Fans: The Psychology and Social Impact of Spectators; Routledge: New York, NY, USA, 2001.

92. Wann, D.L. The "noble" sports fan: The relationships between team identification, self-esteem, and aggression. Percept. Mot. Skills 1994, 78, 864-866. [PubMed]

93. Wann, D.L.; Pierce, S. The Relationship between Sport Team Identification and Social Well-being: Additional Evidence Supporting the Team Identification-Social Psychological Health Model. N. Am. J. Psychol. 2005, 7, 117-124.

94. Wann, D.L.; Inman, S.; Ensor, C.L.; Gates, R.D.; Caldwell, D.S. Assessing the psychological well-being of sport fans using the Profile of Mood States: The importance of team identification. Int. Sports J. 1999, 3, 81-90.

95. Wann, D.L. Understanding the positive social psychological benefits of sport team identification: The team identification-social psychological health model. Group Dyn. Theory Res. Pract. 2006, 10, 272-296. [CrossRef]

96. Wann, D.L.; Waddill, P.J.; Polk, J.; Weaver, S. The team identification-social psychological health model: Sport fans gaining connections to others via sport team identification. Group Dyn. Theory Res. Pract. 2011, 15, 75-89. [CrossRef]

97. Panaccio, A.; Vandenberghe, C. Perceived organizational support, organizational commitment and psychological well-being: A longitudinal study. J. Vocat. Behav. 2009, 75, 224-236. [CrossRef]

98. Galais, N.; Moser, K. Organizational commitment and the well-being of temporary agency workers: A longitudinal study. Hum. Relat. 2009, 62, 589-620. [CrossRef] 
99. Cuskelly, G.; Harrington, M.; Stebbins, R. Changing levels of organizational commitment amongst sport volunteers: A serious leisure approach. Leisure/Loisir 2002, 27, 191-212. [CrossRef]

100. Meyer, J.P.; Allen, N.J.; Smith, C.A. Commitment to organizations and occupations: Extension and test of a three-component conceptualization. J. Appl. Psychol. 1993, 78, 538-551. [CrossRef]

101. Raines-Eudy, R. Using structural equation modeling to test for differential reliability and validity: An empirical demonstration. Struct. Equ. Model. 2000, 7, 124-141. [CrossRef]

102. Fornell, C.; Larcker, D.F. Evaluating structural equation models with unobservable variables and measurement error. J. Mark. Res. 1981, 18, 39-50. [CrossRef]

103. Dai, Y.D.; Hsu, H.L.; Chi, C.S. Relationships among leisure involvement, leisure benefits, and well-being for elders whom participated in mountain hiking: A Study of suburban mountains hiking in Kaohsiung. In Proceedings of the 2008 Annual Conference of Chinese Tourism Management Association, Taipei, Taiwan, 19 December 2008.

104. Popp, B.; Woratschek, H. Introducing branded communities in sport for building strong brand relations in social media. Sport Manag. Rev. 2016, 19, 183-197. [CrossRef]

105. Biscaia, R.; Ross, S.; Yoshida, M.; Correia, A.; Rosado, A.; Marôco, J. Investigating the role of fan club membership on perceptions of team brand equity in football. Sport Manag. Rev. 2016, 19, 157-170. [CrossRef]

106. Nyadzayo, M.W.; Leckie, C.; McDonald, H. CSR, relationship quality, loyalty and psychological connection in sports. Mark. Intell. Plan. 2016, 34, 883-898. [CrossRef]

(C) 2018 by the authors. Licensee MDPI, Basel, Switzerland. This article is an open access article distributed under the terms and conditions of the Creative Commons Attribution (CC BY) license (http://creativecommons.org/licenses/by/4.0/). 